\title{
COMPLIANCE OF THE EU LEGAL ACTS WITH MONTREAL CONVENTION (MC99) ON UNIVERSAL LIABILITY REGIME FOR INTERNATIONAL CARRIAGE BY AIR-IMPORTANCE FOR SUSTAINABLE TOURISM WORLDWIDE
}

\author{
Aleksa Panić*, \\ Marija Kostić
}

Singidunum University, Belgrade, Serbia

\begin{abstract}
:
Entire set of the different international treaty regimes covering airline liability that had developed since 1929 has been unified by this Convention into a single legal act regulating airline liability worldwide. Thus, importance of such a regulation and protection of passenger's rights is obvious in terms of sustainable tourism development and consistency.

Significance of the Montreal Convention (in further text: MC99) has been recognized not only by individual states globally, but also by the European Union itself. According to Chapter VII, Article 53, the MC99 is open for signature not only by single states, but also by any Regional Economic Integration Organizations. The EU has taken advantage over that opportunity and introduced Regulation $889 / 2002$ which fully corresponds to the MC99. Recognizing some shortcomings, the EU made amendments and introduced the Regulation 261/2004.

This article aims to focus on compliance of the EU legal acts with the MC99, in cases of passenger's death or injury, delay in scheduled routes, denied boarding, upgrading and downgrading in cases the air carrier places a passenger in a seat not previously reserved by the passenger. This means that authors have focused on protection of passengers' rights and support for sustainable tourism development worldwide.
\end{abstract}

Keywords:

Montreal Convention MC99, EU Regulations 889/2002\& 261/2004, Liability Regime for International Carriage by Air, Sustainable Tourism Development.

\section{INTRODUCTION}

The EU's Air Passenger Rights Regulation 261/2004 came into force in February 2005 introducing minimal levels of aid and compensation for passengers faced with denied boarding or affected by long delays or cancellations (The European Comission, 2013). The importance of this regulation can certainly be viewed through the prism of sustainability. First of all, focusing on the main aspects of sustainability - economic, social and environmental, this regulation deals with safety and security for tourists or, in this case, passengers. In this regard, it is clear that such regulation allows more worry-free travel planning because tourists know that their rights, regardless of the destination within EU, will be protected.
Correspondence:

Aleksa Panić

e-mail:

apanic@singidunum.ac.rs 
This Regulation is closely related to the MC99, but it still provides additional rights to passengers in cases of denied boarding, cancellation or flight delay. However, in situations of a passenger's death or injury during the flight or during the boarding or leaving the aircraft, liabilities and compensation is regulated by the rules of the Montreal Convention (Živković, 2013). According to Geelhoed (2005), the EU's Regulation doesn't conflict with the main values of the Montreal Convention. He also explains that even the Convention was ratified by EC in 1999, it entered into force 5 years later: "The Convention for the Unification of Certain Rules for International Carriage by Air (hereinafter the 'Montreal Convention') was signed by the European Union on December $9^{\text {th }}, 1999$. It was approved by decision of the Council of April $5^{\text {th }}, 2001$. It entered into force on the territory of the EU on June $28^{\text {th }}$, 2004" (Geelhoed, 2005). IATA describes Montreal Convention as an international legal document which "establishes airline liability in case of death or injury to passengers, as well as in cases of delay, damage or loss of baggage and cargo" (IATA, 2017).

New guidelines have resulted in substantial changes in behaviour in airline industry, in particular compressing the use of denied boarding and commercial cancellations by carriers (with all the disruption that this causes for passengers) as ensuring overall better treatment for passengers on their journey (The European Comission, 2013). This provides greater trust from passengers and contributes to global development of sustainable tourism. When it comes to sustainability on the part of airline operations, such regulations are of particular importance. First of all, clear rights of passengers oblige companies to conduct better training, and in addition, unification of rules prevents the company from inventing rights, i.e. to remain without passengers because certain rights within that company are not guaranteed. In that way, their business remains in domain of market economy, rights of passengers are clearly defined, and passengers will not diversify carriers on that basis.

When we consider sustainability, the important fact is compensation for passengers in case of unfortunate situations. That provides a dose of confidence, security and carefreeness. According to Malenovsky (2016) "the Regulation and the Convention established two separate compensation systems pursuing different objects". Despite, passengers' rights are still protected in both compensation systems.

However, the air companies manage to find gaps in regulations and in case they know that the flight will face cancellation or delay, the management will find a reason that justifies them before the law and releases of liability (Živković, 2013). For example, if an air company faces a delay, the management will probably inform passenger that it is due to some mechanical problem or if there is a cancellation of the flight, they will say that it is due to weather conditions. Some authors notice that it is a clear misunderstanding of interpretation. For example, Deviatnikovaite (2018) states that "although the Regulation and the Convention both relate to protection of air passenger's rights, it remains ambiguous when and in which disputes these acts should be applicable". This is something that should be surpassed by introducing increased control of the compliance of the regulation on protection of passengers. In any case, this regulation ensures maximum efforts to provide a quality travel experience that is an integral part of the overall experience of time spent at a destination. The biggest benefit, logically, have passengers from EU countries, because of the frequency of travel. However, the impact on "third countries" is not negligible, to which by law the regulation does not apply directly, but any connection with EU countries automatically protects the rights of these passengers, regardless of nationality or any other reference of affiliation, and thus helps those countries develop their tourism more prudently.

\section{CASES OF LIABILITY REGIME FOR INTERNATIONAL CARRIAGE BY AIR}

\section{Death or injury}

Unlike some articles of the Montreal Convention, the article devoted to death or injury of passengers hasn't been adjusted or upgraded in the Regulations of the European Commission 889/2002 and 261/2004 and the articles 17 and 21 of the MC99 strictly apply in all signatory countries (Živković, 2013).

With the Montreal Convention introduced, air carriers got greater liability in terms of eventual injuries and deaths of their passengers. Of course, the air company is responsible only if the injury or the death happened during the flight, or during entering or leaving the aircraft (International Air Transport Association (IATA), 1999). 
According to Article 21 of the MC99, for damages up to 100000 SDRs the air companies cannot avoid their obligation to compensate passengers. Above that amount, the air carrier can defend itself by proving that the fault was not caused on purpose or due to negligence of either an air company's staff or an agent (The European Parliament and the Council, 2002).

In case of death or injury of a passenger, the air company must make a prepayment in order to cover the immediate economic urgency and within 15 days from the day the person entitled to reimbursement has been identified. In case of death, the advance payment should not be lower than 16000 SDRs (The European Parliament and the Council, 2002).

These decisions arising from the Montreal Convention ensure that passengers or, in the worst-case scenario, their families be reimbursed in a fair manner. Moreover, it motivates air companies to invest more in crew training so they would be able to act in the most adequate way. In addition, an airline management is now aware of necessity of modern equipment in an aircraft, especially ones intended for saving human life.

\section{Delay}

Delay in scheduled routes of any kind, so in air transport as well, is one of the most challenging issues in modern era of transport. It may occur due to bad weather, air traffic management, airport capacity, airline technical and operational matters, behaviour of other passengers, and behaviour of other airlines or some external factors (McDonald, 2003).

Article 19 of the MC99 clearly indicates that in case of passenger, cargo or baggage delay, the air company is responsible for damage unless it proves that it took all possible measures to avoid the delay or it was impossible to take such measures (International Air Transport Association (IATA), 1999). However, it is not mentioned what kind of measures the air company is expected to apply in order to avoid the responsibility, which leaves airlines with room for a manoeuvre in order to avoid liability.

According to the EC Regulation 261/2004, if a passenger is denied boarding or their flight has been cancelled or overbooked, they have a right to ask for alternative ways of transportation to their final destination or to ask for ticket refund and in if the situation allows, asked to be returned to their initial departure point. In case of long delays, which means 5 hours or more, a traveller may also ask for a refund, but in that case, air carrier doesn't have to provide any additional onward travel or assistance. In addition, every airline must inform its passengers about the reasons for the delays, if the delay would last 2 hours or more, or any cancellation or denied boarding. Furthermore, the airline must inform its customers about their rights regarding this matter (European Comission, 2013).

\section{Denied Boarding}

According to Article 4 of EC Regulation 261/2004, in case when, for any reason, Air Company may anticipate deny of boarding, it should first ask for any volunteers willing to negotiate compensation and future benefits in return for their reservation retrieval. If it turns out that there are no many volunteers, the air company may decide to deny boarding against the will of passengers. That decision would cause call on liability of the air company and compensation should be paid to passengers (The European Parliament and the Council, 2004). That definitely motivates air companies to give their best to find a solution and avoid paying compensation and penalties to passengers.

Still, in case they do not motivate passengers enough to voluntarily give their reservations back, the liability which the air company has is regulated under the articles 7, 8 and 9 and it depends on how long the boarding is denied or postponed. In case of up to 4 hours delay, the air company is, according to EC 261/2004, Article 9, Right to Care, obligated to provide passengers with meals and refreshments and two free of charge calls or any other form of communication.

In case of a delay lasting longer than 4 hours, the air company should, in addition to the above mentioned, provide a recompense to passengers if they want to cancel the trip. Furthermore, airline management should provide free accommodation and transfer to and from the hotel (The European Parliament and the Council, 2004). 
These articles stated in the EC Regulation 261/2004 serve as a shield to passengers, because otherwise air companies would offer very low compensation deals, or they would deprive passengers from getting benefits afterwards. However, it is not stated, for example, what level of quality should accommodation be, or what kind of meals the passengers should get. So, there is a room for the air company to save some money and provide passengers with lower-quality accommodation or meals.

One of the most common reasons for denied boarding is overbooking due to a mistake or misperception of the airline. Obviously, it is the airline's fault and a passenger may ask for a refund.

The proposed mandatory and immediately payable compensation amounts vary depending on the distance to a destination on the ticket:

1. $250 € \rightarrow 0-1.000$ kilometres;

2. $400 € \rightarrow$ all intra-Community flights of more than 1500 kilometres, and for all other flights between 1500 and 3500 kilometres

3. $600 € \rightarrow$ all other sort of flights.

(McDonald, 2003)

\section{Upgrading and downgrading}

In the Regulation EC 261/2004, one rather important article has been introduced. Sometimes the airline puts a passenger in a seat which was not previously reserved by the passenger. In the article 10 it is stated what the consequences should be in case of placing a passenger in a different class - if the passenger is placed in a higher class, there is no need for any supplementary payment. But, if the passenger is placed in a lower class, the air company should reimburse them within 7 days:

a. For flights 0 to $1500 \mathrm{~km} \rightarrow 30 \%$ of the price of the ticket;

b. For all intra-Community flights of more than 1500 kilometres, except flights between the European union and the French overseas departments-regions, and for all other flights between 1500 and 3500 kilometres $\rightarrow 50 \%$

c. All other flights $\rightarrow 75 \%$

(The European Parliament and the Council, 2004)

It is possible that a reason such measure has not been developed earlier is that there was no reason for it - the air transport was not as developed and situations such as these were not common. However, with the number of passengers on the increase, it is possible that the air company makes overbooking or any other kind of mistake which would lead to placing the passenger in a wrong class. That is why it is good that such protection has been introduced and it should be used to force air carriers to pay more attention on how they make reservations and distribution of the passengers.

\section{CONCLUSION}

The Montreal Convention, with all its positive and less positive aspects, brought necessary refreshment in the developed and modernized air industry, as well as tourism industry indirectly. Air carriers must be aware that without passengers there is no reason for their existence and therefore, keeping their passengers happy, satisfied and safe should be among their main concerns. There is no business or a company without both internal and external problems, hence in the air industry as well. However, all parties involved in securing safe air transportation for passengers must use all of their efforts and take advantage of their responsibilities in order to prevent and minimize the failures in service. That is the only way they can develop their business and ensure its sustainability. Offering the adequate compensation if an accident occurs would most likely be enough for an injured passenger to choose the same company again to fly with. On the contrary, it could damage the reputation of the company because most of those cases finish in public. Every air company, like any other hotel or a company is some other business, strives to gain as much loyal customers, as possible. 
Therefore, losing the existing passengers would mean losing revenue and if it loses revenue because it does not accept its fault or try to cover and avoid it, then that company could easily be taken out of business.

In addition to importance for sustainable development of tourism, in our case more specific passengers and airlines, an additional aspect is the sustainable development of the destinations themselves. Hereby, it is necessary to mention the important aspect of tourism industry and that would be sustainability. Tourism is one of the fastest growing industries in the world, which has significant impact on natural resources, consumption patterns, pollution, and socio-economic systems. Sustainable tourism makes a minimal impact on environment and local culture, while contributing to overall development by helping generate future employment for local people and bringing a positive experience for tourism companies and tourists themselves (Kostić \& JovanovićTončev, 2014).

Regulation discussed in this article enables tourist entities to plan tourism development without hindrance, because there is no fear that tourists from a certain country will not come because they are afraid of the outcome of the trip, or that in case of unwanted and unplanned situations their rights remain unprotected. The principles of sustainable tourism should be the guiding principles of each stakeholder that defines the tourist offer. Thanks to this regulation, and the Montreal Convention, of course, the business of tourism entities is significantly facilitated and tourists, i.e. passengers, are additionally motivated to travel because their rights are protected and, moreover, companies are obliged to inform them about it. In this way, that ensures a sustainable business and possibility of long-term planning of tourism development and operations in these areas. It can be said that such a regulation not only protects the rights of passengers but also enables tourism entities to plan their activities much easier and more carefree, knowing that tourists will not cancel their arrivals for fear of unforeseen and unwanted situations during the trip.

With further modernization and development of the industry, there will be need for further regulations to be adopted, as was the case before the Montreal Convention. The European Union is a leader in this legislation process, but air industry's officials still must put their efforts to ensure that the Montreal Convention is implemented, as well as all other existing laws and regulations in order to maintain the reputation of the airline transport as the safest and the most sustainable way of travelling and to send the message that all air passengers are equal and that their rights are recognized and fully protected.

\section{REFERENCES}

Deviatnikovaite, I. (2018). The Montreal Convention of 1999 and regulation no 261/2004 in the EUCJ and national case law. Baltic Journal of Law \& Politics, 11(1),, 21-47, DOI: 10.2478/bjlp-2018-0002

European Comission. (2013). Air passenger rights. Retrieved May 20, 2020, from Europa.eu.

Geelhoed, M. Opinion of Mr Advocate General Geelhoed delivered on 8 September 2005. The Queen, on the application of International Air Transport Association and European Low Fares Airline Association vs. Department for Transport, Case C-344/04, European Court Reports 2006 I-00403

International Air Transport Association (IATA). (2017). A Universal Liability Regime For International Carriage by Air - Montreal Convention 1999 Retrived May 21,2020, from https://www.iata.org/contentassets/ fb1137ff561a4819a2d38f3db7308758/position-paper-mc99-july-2017.pdf

International Air Transport Association (IATA). (1999). The Montreal Convention 1999 (MC99). Retrieved May 10, 2020, from International Air Transport Association (IATA) Web site: http://www.iata.org/policy/ Documents/MC99_en.pdf

Kostić, M., \& Jovanović Tončev, M., Importance of sustainable tourism, in Sinteza 2014 - Impact of the Internet on Business Activities in Serbia and Worldwide, 722-725, Belgrade, Singidunum University, Serbia, 2014, DOI: 10.15308/SInteZa-2014-722-725

Malenovský, J. (2016). Regulation 261: Three Major Issues in the Case Law of the Court of Justice of the EU. In M. Bobek, \& J. Prassl, Air Passenger Rights. Ten Years On, 21-47, Oxford and Portland, Oregon: Hart Publishing.

McDonald, M. (2003). European Community Tourism Law and Policy, Dublin, Blackhall.

The European Comission. (2013). Press realeases - Air Passenger Rights Revision - Frequently asked questions. Retrieved May 20, 2020, from Europa.eu: http://europa.eu/rapid/press-release_MEMO-13-203_en.htm 
The European Parliament and the Council. (2002). Regulation (EC) No 889/2002 of the European Parliament and the Council. Retrieved May 22, 2020, from Official Journal of the European Communities.

The European Parliament and the Council. (2004). Regulation (EC) No 261/2004 of the European Parliament and of the Council. Retrieved May 22, 2020, from http://eur-lex.europa.eu/LexUriServ/LexUriServ. do? uri=CELEX:32004R0261:EN:HTML

Živković, R. (2013). Ponašanje i zaštita potrošača u turizmu [Behavior and Consumer Protection in Tourism]. Beograd: Fakultet za turistički i hotelijerski menadžment, Univerzitet Singidunum. 